\title{
Does activation of the protective Renin- Angiotensin System have therapeutic potential in COVID-19?
}

\author{
Pawel Namsolleck ${ }^{1}$ and Gert N. Moll ${ }^{1,2^{*}}$ (D)
}

\begin{abstract}
Infection of lung cells by the corona virus results in a loss of the balance between, on the one hand, angiotensin IImediated stimulation of the angiotensin II type 1 receptor and, on the other hand, stimulation of the angiotensin II type 2 receptor and/or the Mas receptor. The unbalanced enhanced stimulation of the angiotensin II type 1 receptor causes inflammation, edema and contributes to the pathogenesis of severe acute respiratory distress syndrome. Here we hypothesize that stable, receptor-specific agonists of the angiotensin II type 2 receptor and of the Mas receptor are molecular medicines to treat COVID-19 patients. These agonists have therapeutic potential in the acute disease but in addition may reduce COVID-19-associated long-term pulmonary dysfunction and overall end-organ damage of this disease.
\end{abstract}

Keywords: COVID-19, ARDS, ACE2, Angiotensin, AT, R, AT 2 R, MasR

Recent publications highlight ACE2 as a cell-entry receptor for SARS-CoV and SARS-CoV-2. Less attention is given to other, in particular protective, components of the Renin Angiotensin System (RAS) (Unger et al. 2015). RAS has a double nature, like the two-faced ancient Roman god Janus, which simultaneously looks in opposite directions. The Detrimental Arm of RAS is formed by the ACE-Angiotensin II (Ang II)-angiotensin II type 1 receptor $\left(\mathrm{AT}_{1} \mathrm{R}\right)$ axis. Limiting the detrimental effects of $\mathrm{AT}_{1} \mathrm{R}$ by $\mathrm{AT}_{1} \mathrm{R}$ blockers (ARBs) or by inhibiting RAS via ACE inhibitors (ACEi) is generally well-established. However, the use of ARBs and ACEi in coronavirus disease-2019 (COVID-19) has been subject of debate. On the other hand, as part of the Protective Arm of RAS, Ang II also stimulates the angiotensin II type 2 receptor $\left(\mathrm{AT}_{2} \mathrm{R}\right)$ and this octapeptide can be further cleaved by the carboxypeptidase ACE2 to yield angiotensin-(1-7) (Ang-(1-7)), an agonist of the Mas receptor (MasR). The

\footnotetext{
* Correspondence: moll@lanthiopharma.com; g.n.moll@rug.nl 'Lanthio Pharma, a MorphoSys AG company, Rozenburglaan 13B, 9727 DL Groningen, the Netherlands

${ }^{2}$ Department of Molecular Genetics, Groningen Biomolecular Sciences and Biotechnology Institute, University of Groningen, Nijenborgh 7, 9747 AG Groningen, the Netherlands
}

(C) The Author(s). 2020 Open Access This article is licensed under a Creative Commons Attribution 4.0 International License, which permits use, sharing, adaptation, distribution and reproduction in any medium or format, as long as you give appropriate credit to the original author(s) and the source, provide a link to the Creative Commons licence, and indicate if changes were made. The images or other third party material in this article are included in the article's Creative Commons licence, unless indicated otherwise in a credit line to the material. If material is not included in the article's Creative Commons licence and your intended use is not permitted by statutory regulation or exceeds the permitted use, you will need to obtain permission directly from the copyright holder. To view a copy of this licence, visit http://creativecommons.org/licenses/by/4.0/.

protective effects of $\mathrm{AT}_{2} \mathrm{R}$ and MasR agonists are usually opposite to the detrimental effects of $\mathrm{AT}_{1} \mathrm{R}$, but their clinical use, in cases of unbalance between the two Arms of RAS, is insufficiently explored. Endogenous ligands of the RAS receptors are rapidly degraded and lack receptor specificity. Here we consider therapeutic perspectives of stable and specific $\mathrm{AT}_{2} \mathrm{R}$ and MasR agonists in COVID-19.

The balance between the Detrimental and Protective Arm of RAS is in several aspects seriously disturbed in COVID-19, thus causing a potentially lethal disease (Fig. 1). After the SARS-CoV cell-entry following ACE2-interaction, subsequent down-regulation of cell surface ACE2 is observed (Kuba et al. 2005). Since SARS-CoV-2 also targets ACE2, likewise downregulation of ACE2 is expected. Reduced membrane expression of ACE2 enhances the inflammatory response to the virus. COVID-19 infection furthermore causes an increase in the decapeptide Ang I and the octapeptide Ang II, whereas Ang-(1-7) levels decrease. Thereby detrimental Ang II-mediated stimulation of $\mathrm{AT}_{1} \mathrm{R}$ is enhanced whereas protective Ang-(1-7)-mediated stimulation of MasR is decreased. $\mathrm{AT}_{1} \mathrm{R}$ stimulation reduces alveolar cell survival. It also causes inflammation 


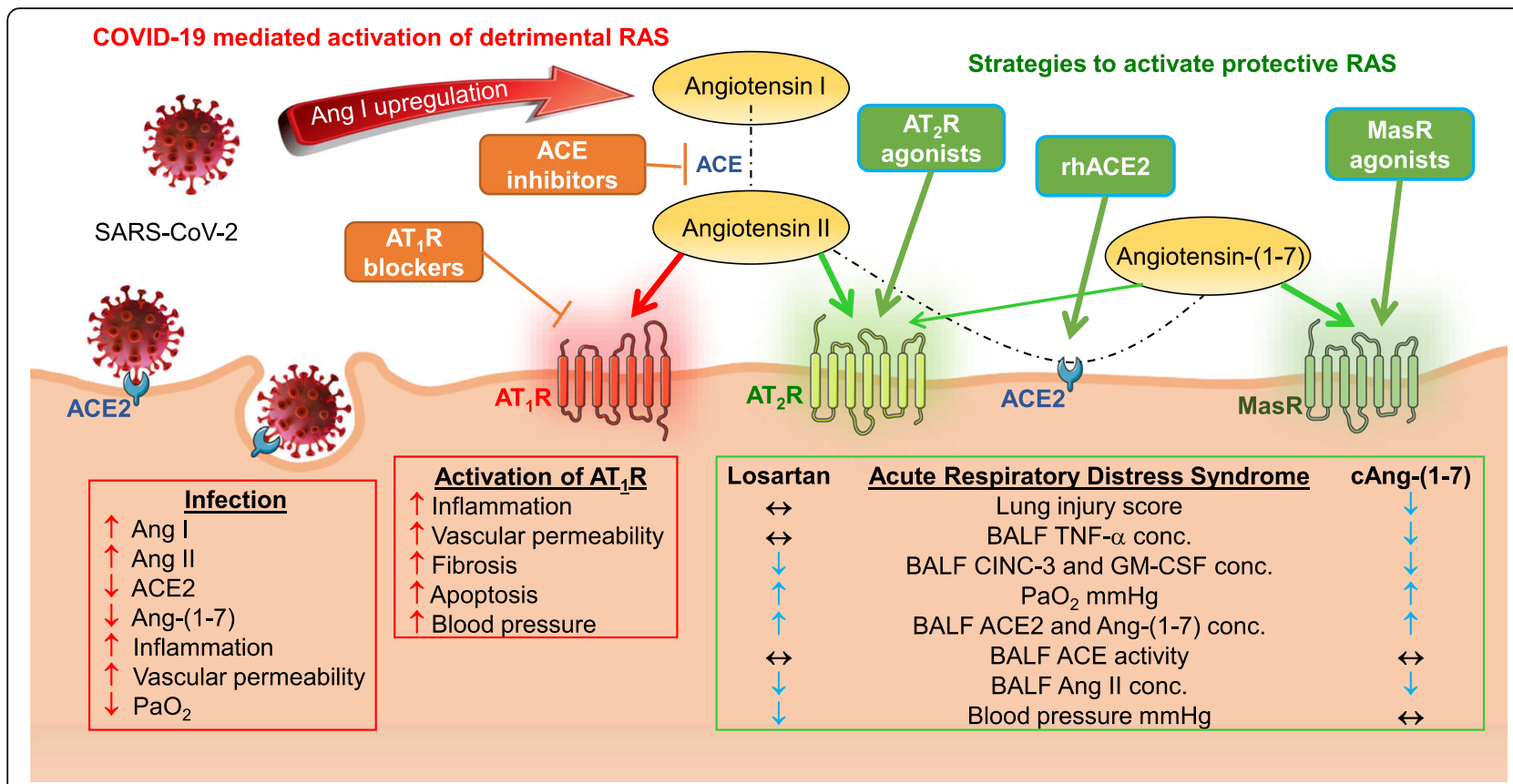

Fig. 1 Potential treatments of SARS-CoV-2 infection within the Renin Angiotensin System containing a summary of an animal model of acute respiratory distress syndrome (Wösten-van Asperen et al. 2011)

and an increase in vascular permeability (Huertas et al. 2020). As a result, edema is accumulating in the alveoli which hampers gas-exchange leading to lower oxygen levels. Taken together this adds to the severity of the acute respiratory distress.

Reduction of the unbalance in the RAS by inhibition of the Detrimental Arm might be reached by either an ARB or an ACEi. The combined use of ARBs and ACEi is prohibited, but their single use is applied. ARBs block the $\mathrm{AT}_{1} \mathrm{R}$ and thus Ang II can activate the unopposed protective receptor $\mathrm{AT}_{2} \mathrm{R}$ and further, after ACE2-mediated conversion of Ang II into Ang-(1-7), also the MasR. Unfortunately, ARBs exert only limited therapeutic effect in tissue injury (Unger et al. 2015). Moreover, ARBs may reduce blood pressure, which in case of critically ill patients may lead to unwanted hypotension. ACEi block the ACEmediated cleavage of Ang I and thereby block the formation of Ang II. Pros and cons of the use of ARBs and ACEi in COVID-19 have been discussed (D'Ardes et al. 2020). Continuation of the use of an ARB or an ACEi in COVID19 has been recommended (Vaduganathan et al. 2020; Ingraham et al. 2020; Park et al. 2020; Sanchis Gomar et al. 2020) and has been suggested to be beneficial in cardiovascular disease (Wang et al. 2020). Fear for induction of upregulation of the CoV-2-receptor ACE2 leading to enhanced infection (Sommerstein and Gråni 2020) has not been supported by clinical data (Gupta and Misra 2020; Kai and Kai 2020). In fact a clinical investigation demonstrated that no ARB or ACEi-induced upregulation of ACE2 takes place (Sriram and Insel 2020). On the other hand, benefits with respect to reducing COVID-19 itself have not (yet) been demonstrated in the clinic either (Gupta and Misra 2020; Kai and Kai 2020; Rico-Mesa et al. 2020). Instead of blocking $\mathrm{AT}_{1} \mathrm{R}$ or inhibiting $\mathrm{ACE}$, here we focus on the potential benefits in COVID-19 of stimulating the $\mathrm{AT}_{2} \mathrm{R}$ or MasR.

Restoration of the balance in the RAS after corona virus infection might be pursued by direct and specific stimulation of the Protective Arm via $\mathrm{AT}_{2} \mathrm{R}$ or via the ACE2 - Ang-(17) - MasR axis. In a subchronic lung injury model a cyclized $\mathrm{AT}_{2} \mathrm{R}$-specific peptide agonist, with a half-life of $>2 \mathrm{~h}$ in man, reduced inflammation and hypertrophy (Wagenaar et al. 2013). In an animal model of monocrotaline-induced pulmonary hypertension, a small molecule $\mathrm{AT}_{2} \mathrm{R}$ agonist C21 reversed pulmonary fibrosis and prevented right ventricular fibrosis. Furthermore C21 improved right heart function, decreased pulmonary vessel wall thickness, and reduced pro-inflammatory cytokines (Bruce et al. 2015). In a bleomycin-induced lung injury model prolonged administration of the $\mathrm{AT}_{2} \mathrm{R}$ agonist $\mathrm{C} 21$ prevented and attenuated pulmonary fibrosis, collagen deposition and lung remodeling. In addition C21 reduced inflammation, improved lung pressure and reduced muscularization of the pulmonary vessels (Rathinasabapathy et al. 2018). Currently the safety and efficacy of this agonist is tested in a Phase 2 trial with patients with COVID-19 infection (ClinicalTrials.gov Identifier: NCT04452435).

Recombinant human ACE2, which is not membrane bound, still binds to the corona virus and thereby limits the cell entry (Fig. 1). Furthermore recombinant ACE2 converts 
Ang II into Ang-(1-7). In patients with pulmonary arterial hypertension a single dose of recombinant human ACE2 resulted in a decreased level of pro-inflammatory cytokines and markers of oxidative stress accompanied by decreased pulmonary vascular resistance and increased cardiac output (Hemnes et al. 2018). To elucidate the molecular mechanisms leading to the observed effects, RNAseq on pulmonary arteries treated ex vivo with MasR agonist AVE0991 was performed. Significant changes in pressure regulation, inflammatory responses and cell migration pathways were observed indicating therapeutic effects of MasR activation
(Hemnes et al. 2018). Stimulation of the MasR reduces in vitro Ang II- or bleomycin-induced apoptosis of alveolar epithelial cells (Uhal et al. 2011).

A recent review speculates on potential benefits of MasR stimulation in COVID-19 based on data obtained from animal models of asthma, lung fibrosis, ARDS, and pulmonary emphysema. The anti-inflammation effects, such as decreased cytokine and chemokine synthesis, migration of inflammatory cells to the lung and the resulting functional improvement of the lungs would be key benefits of MasR stimulation (Fig. 2). In addition, prolonged treatment might

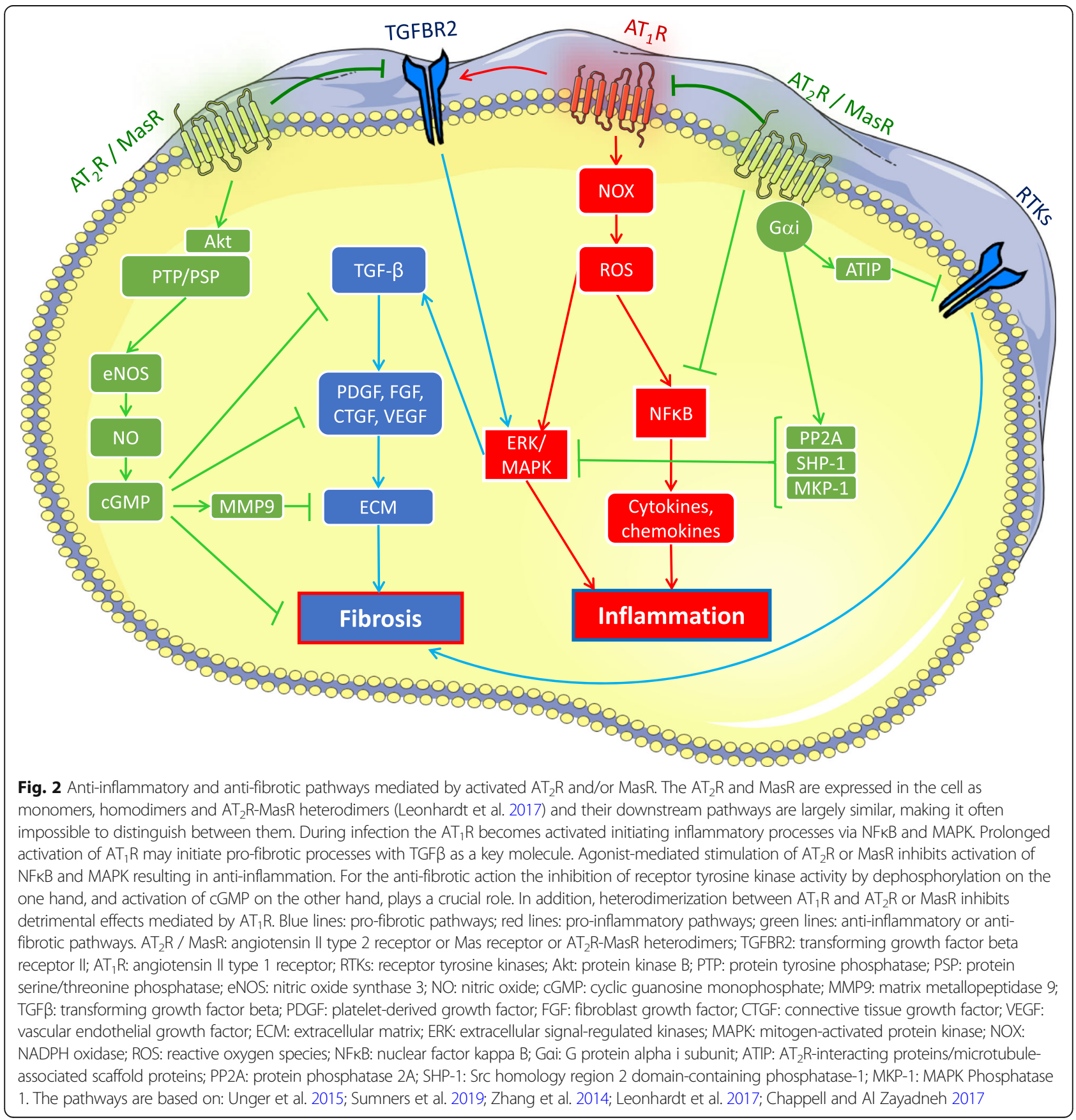


result in anti-fibrotic effects in lung tissue (Magalhaes et al. 2020).

The potential of the ACE2 - Ang-(1-7) - MasR axis has furthermore been recognized as witnessed by registered clinical trials of Ang-(1-7) in COVID-19 (ClinicalTrials.gov, Identifiers: NCT04332666; NCT04375124; NCT04401423). However, endogenous Ang-(1-7) lacks receptor specificity. Ang-(1-7) stimulates in vivo the MasR but in vitro studies reported biased agonism at the $\mathrm{AT}_{1} \mathrm{R}$ (Galandrin et al. 2016). In addition, Ang-(1-7) is very rapidly degraded resulting in a half-life of less than a minute in man. In contrast, specific and stable cyclic Ang-(1-7) exerts multiple therapeutic effects in lung tissue of animal models of acute and chronic lung injury (Wagenaar et al. 2013; Wösten-van Asperen et al. 2011).

In an animal model of ARDS, cyclic Ang-(1-7) reduced lung injury and inflammation while improving blood oxygenation (Fig. 1). Cyclic Ang-(1-7), which is fully ACE-resistant, did not change the blood pressure (Wösten-van Asperen et al. 2011). In addition to the acute and sub-chronic effects in COVID-19, stable $\mathrm{AT}_{2} \mathrm{R}$ agonists (Bruce et al. 2015) may reduce COVID-19associated long term pulmonary dysfunction.

Besides the lungs, COVID-19 also affects heart, kidney, liver, gastrointestinal and the central nervous systems (Gan et al. 2020). In view of the demonstrated general therapeutic potential of the Protective Arm of RAS in these organs and systems (Unger et al. 2015), treatment of severe ARDS in COVID-19 with $\mathrm{AT}_{2} \mathrm{R}$ and MasR agonists may concomitantly confer beneficial effects that reduce the overall end-organ damage of this disease.

In conclusion, available data indicate the perspective of an effective strategy for treatment of ARDS and COVID-19 by direct and selective stimulation of the Protective Arm of RAS by $\mathrm{AT}_{2} \mathrm{R}$ - or MasR-specific, peptidase-resistant agonists. The data converge to further investigations in viral pneumonia-mediated ARDS models.

\section{Abbreviations}

RAS: Renin angiotensin system; SARS: Severe acute respiratory syndrome; CoV-2: Coronavirus 2; COVID-19: Coronavirus disease 2019; ARDS: Acute respiratory distress syndrome; $\mathrm{AT}_{2} \mathrm{R}$ : Angiotensin II type 2 receptor; MasR: Mas receptor; ARB: Angiotensin II type 1 receptor blocker; ACE: Angiotensin converting enzyme; ACEi: Angiotensin converting enzyme inhibitor; Ang II: Angiotensin II; Ang-(1-7): Angiotensin-(1-7)

\section{Acknowledgements}

Not applicable.

\section{Authors' contributions}

PN wrote the first version of the manuscript which has been extended by GNM. The author(s) read and approved the final manuscript.

\section{Funding}

No funding for this work has been received.
Ethics approval and consent to participate Not applicable.

\section{Consent for publication}

Both authors read and agreed to the content of the final manuscript, and consented on its publication.

\section{Competing interests}

The authors disclose that their employer, LanthioPep B.V., is owner of patents on angiotensin variants. GNM is director of LanthioPep B.V.

Received: 27 June 2020 Accepted: 11 August 2020

Published online: 17 August 2020

\section{References}

Bruce E, Shenoy V, Rathinasabapathy A, et al. Selective activation of angiotensin AT2 receptors attenuates progression of pulmonary hypertension and inhibits cardiopulmonary fibrosis. Br J Pharmacol. 2015;172:2219-31.

Chappell MC, Al Zayadneh EM. Angiotensin-(1-7) and the regulation of antifibrotic signaling pathways. J Cell Signal. 2017;2(1):134.

D'Ardes D, et al. COVID-19 and RAS: Unravelling an unclear relationship. Int J Mol Sci. 2020;21(8):3003.

Galandrin S, Denis C, Boularan C, et al. Cardioprotective angiotensin-(1-7) peptide acts as a natural-biased ligand at the angiotensin II type 1 receptor. Hypertension. 2016;68:1365-74.

Gan R, Rosoman NP, Henshaw DJE, et al. COVID-19 as a viral functional ACE2 deficiency disorder with ACE2 related multi-organ disease. Med Hypotheses. 2020;144:110024

Gupta R, Misra A. Contentious issues and evolving concepts in the clinical presentation and management of patients with COVID-19 infection with reference to use of therapeutic and other drugs used in co-morbid diseases. Diabetes Metab Syndr. 2020;14:251e254.

Hemnes AR, et al. A potential therapeutic role for Angiotensin Converting Enzyme 2 in human pulmonary arterial hypertension. Eur Respir J. 2018;51(6): 1702638.

Huertas A, Montani D, Savale L, et al. Endothelial cell dysfunction: a major player in SARS-CoV-2 infection (COVID-19)? Eur Respir J. 2020;56(1):2001634.

Ingraham NE, Barakat AG, Reilkoff $R$, et al. Understanding the renin-angiotensinaldosterone-SARS-CoV-Axis: a comprehensive review. Eur Respir J. 2020;56(1): 2000912.

Kai H, Kai M. Interactions of coronaviruses with ACE2, angiotensin II, and RAS inhibitors-lessons form available evidence and insights into COVID-19. Hypertens Res. 2020. https://doi.org/10.1038/s41440-020-0455-8 [Epub ahead of print].

Kuba K, Imai Y, Rao S, et al. A crucial role of angiotensin converting enzyme 2 (ACE2) in SARS coronavirus-induced lung injury. Nat Med. 2005;11:875-9.

Leonhardt J, Villela DC, Teichmann A, et al. Evidence for heterodimerization and functional interaction of the angiotensin type 2 receptor and the receptor MAS. Hypertension. 2017;69(6):1128-35.

Magalhaes GS, Rodrigues-Machado MDG, Motta-Santos D, Campagnole-Santos MJ, Santos RAS. Activation of Ang-(1-7)/mas receptor is a possible strategy to treat coronavirus (SARS-CoV-2) infection. Front Physiol. 2020;11:730.

Park S, et al. Is the use of RAS inhibitors safe in the current era of COVID-19 pandemic? Clin Hypertens. 2020;26:11

Rathinasabapathy A, et al. The selective angiotensin II type 2 receptor agonist, compound 21, attenuates the progression of lung fibrosis and pulmonary hypertension in an experimental model of bleomycin-induced lung injury. Front Physiol. 2018;9:180.

Rico-Mesa JS, White A, Anderson AS. Outcomes in patients with COVID-19 infection taking ACEi/ARB. Curr Cardiol Rep. 2020;22:31.

Sanchis Gomar F, et al. Angiotensin-converting enzyme 2 and antihypertensives (angiotensin receptor blockers and angiotensin-converting enzyme inhibitors) in coronavirus disease 2019. Mayo Clin Proc. 2020;95:1222-30.

Sommerstein R, Gråni C. Rapid resonse: preventing a Covid-19 pandemic: ACE inhibitors as a potential risk factor for fatal Covid-19. BMJ. 2020;368:m810.

Sriram K, Insel PA. Risk of ACE inhibitor and ARB usage in Covid-10: evaluating the evidence. Clin Pharmacol Ther. 2020;108(2):236-41.

Sumners C, Peluso AA, Haugaard AH, Bertelsen JB, Steckelings UM. Anti-fibrotic mechanisms of angiotensin AT2 -receptor stimulation. Acta Physiol (Oxf). 2019;227(1):e13280. 
Uhal BD, Li X, Xue A, Gao X, Abdul-Hafez A. Regulation of alveolar epithelial cell survival by the ACE-2/angiotensin 1-7/mas axis. Am J Physiol Lung Cell Mol Physiol. 2011;301(3):L269-74.

Unger T, Steckelings UM, dos Santos RAS. The protective arm of the renin angiotensin system. Functional aspects and therapeutic implications. ISBN 978-0-12-801364-9 1st ed. Academic Press: Elsevier; 2015.

Vaduganathan M, Vardeny $\mathrm{O}$, Michel T, et al. Renin-angiotensin-aldosterone system inhibitors in patients with Covid-19. N Engl J Med. 2020;382:1653-9.

Wagenaar GT, Laghmani el H, Fidder M, et al. Agonists of MAS oncogene and angiotensin II type 2 receptors attenuate cardiopulmonary disease in rats with neonatal hyperoxia-induced lung injury. Am J Physiol Lung Cell Mol Physiol. 2013;305:L341-51.

Wang JJ, et al. Good or bad: application of RAAS inhibitors in COVID-19 patients with cardiovascular comorbidities. Pharmacol Ther. 2020;215:107628.

Wösten-van Asperen RM, Lutter R, Specht PA, et al. Acute respiratory distress syndrome leads to reduced ratio of ACE/ACE2 activities and is prevented by angiotensin-(1-7) or an angiotensin II receptor antagonist. J Pathol. 2011;225: 618-27.

Zhang Z, Chen L, Zhong J, Gao P, Oudit GY. ACE2/Ang-(1-7) signaling and vascular remodeling. Sci China Life Sci. 2014;57(8):802-8.

\section{Publisher's Note}

Springer Nature remains neutral with regard to jurisdictional claims in published maps and institutional affiliations.

Ready to submit your research? Choose BMC and benefit from:

- fast, convenient online submission

- thorough peer review by experienced researchers in your field

- rapid publication on acceptance

- support for research data, including large and complex data types

- gold Open Access which fosters wider collaboration and increased citations

- maximum visibility for your research: over $100 \mathrm{M}$ website views per year

At BMC, research is always in progress.

Learn more biomedcentral.com/submissions 